\title{
Neuropathic Pain After Total Knee Arthroplasty: A Cross-sectional Study in Female Patients
}

\author{
Total Diz Artroplasti Sonrası Nöropatik Ağrı: Kadın Hastalarda Kesitsel Bir Çalışma \\ (1) Cemile Sevgi Polat, (1) Didem Sezgin Özcan, (1) Elif Umay Altaş, (1) Şule Şahin Onat, (1) Belma Füsun Köseoğlu \\ Ankara Physical Therapy and Rehabilitation Training and Research Hospital, Clinic of Physical Therapy and Rehabilitation, Ankara, Turkey
}

\section{Abstract}

Objective: This study aimed to investigate the presence of neuropathic pain (NP) in female patients after total knee arthroplasty (TKA) along with NP-associated factors.

Materials and Methods: In total, 85 female patients who underwent TKA due to knee osteoarthritis were included in this study. Sociodemographic factors along with medical and psychological comorbidities were investigated. Pain levels were assessed using the visual analogue scale (VAS) and Western Ontario and McMaster Universities Arthritis Index (WOMAC) pain scales. The functional status was assessed using the WOMAC physical function scales. Importantly, the presence of NP was assessed using the PainDETECT questionnaire. The emotional status of the patients was assessed using the hospital anxiety depression scale.

Results: In total, 9 (10.6\%) patients were classified as having likely NP and 14 (16.5\%) as having possible NP. The PainDETECT scores were significantly correlated with the preoperative VAS scores $(p=0.004)$, WOMAC pain $(p=0.000)$ and physical function scores ( $p=0.007$ ) and presence of depression $(p=0.021)$ Furthermore, the PainDETECT scores were significantly negatively correlated with the period after arthroplasty $(p=0.033$ ). No correlation was found between NP and socio-demographic factors and medical comorbidities.

Conclusion: Patients with NP had a shorter period after arthroplasty, depression, an increased severity of pain and a decreased physical function. The presence of NP in the patients who underwent TKA should be considered and associated factors should be evaluated.

Keywords: Neuropathic pain, total knee arthroplasty, functional status, depression

\section{Öz}

Amaç: Çalışmanın amacı total diz protezinden (TKA) sonra nöropatik ağrı (NP) varlı̆ı̆ını ve NP’nin sosyo-demografik faktörler, fiziksel fonksiyon, medikal ve psikolojik komorbiditeler ile ilişkisini araştırmaktır.

Gereç ve Yöntem: Diz osteoartriti nedeni ile TKA olan 85 kadın hasta çalışmaya dahil edildi. Sosyo-demografik faktörler, medikal ve psikolojik komorbiditeler sorgulandı. Ağrı şiddeti görsel analog skala (VAS) ve Western Ontario ve McMaster Üniversiteleri Artrit İndeksi (WOMAC) ağrı skalası ile, fonksiyonel durum WOMAC fiziksel fonksiyon skalası ile, NP varlığı PainDETECT Ağrı anketi ile, hastaların emosyonel durumu hastane anksiyete depresyon skalası ile değerlendirildi.

Bulgular: Dokuz hasta $(\% 10,6)$ NP pozitif, 14 hasta $(\% 16,5)$ muhtemel NP olarak sınıflandırıldı. PainDETECT skorları ile operasyon öncesi VAS skorları $(p=0,004)$, WOMAC ağıı $(p=0,000)$ ve fiziksel fonksiyon skorları $(p=0,007)$ ve depresyon varlı̆ı $(p=0,021)$ arasında anlamlı pozitif korelasyon, artroplastiden sonra geçen zaman ile arasında negatif korelasyon ( $p=0.033$ ) saptandı. NP ve sosyo-demografik faktörler ve medikal komorbiditeler arasında ilişki saptanmadı.

Sonuç: Bu çalışmanın sonuçları TKA sonrası bazı hastalarda NP olduğunu gösterdi. NP'si olan hastaların artroplasti sonrası dönemin daha kısa olduğu ve bu hastaların depresyonu olduğu, ağrı ve disabilitesinin artmış olduğu saptandı. TKA hastalarında NP varlığı düşünülmeli ve ilişkili faktörler değerlendirilmelidir. TKA sonrası ağrı tedavisinde NP için uygun tedavi stratejileri dahil edilmelidir.

Anahtar kelimeler: Nöropatik ağrı, total diz artroplastisi, fonksiyonel durum, depresyon

Address for Correspondence/Yazışma Adresi: Cemile Sevgi Polat MD, Ankara Physical Therapy and Rehabilitation Training and Research Hospital, Clinic of Physical Therapy and Rehabilitation, Ankara, Turkey

Phone: +90 5056354605 E-mail: drsevgipolat@hotmail.com ORCID ID: orcid.org/0000-0002-1037-1476

Received/Geliş Tarihi: 29.07.2020 Accepted/Kabul Tarihi: 30.11.2020

${ }^{\circ}$ Copyright 2021 by the Turkish Osteoporosis Society / Turkish Journal of Osteoporosis published by Galenos Publishing House 


\section{Introduction}

Total knee arthroplasty (TKA) is usually performed in patients with end-stage osteoarthritis of the knee when conservative treatments are insufficient. Severe pain is one of the most important causes for arthroplasty in patients with end-stage osteoarthritis (1). Some patients continue to complain of pain in the operated joint after TKA (2-5). Although this pain can be inflammatory, nociceptive or neuropathic in nature, the most common diagnosis is neuropathic pain (NP) in patients with chronic pain after knee surgery (6). NP does not usually respond to simple analgesics and specific management strategies are needed (7). Peripheral nerve injury during surgery or impaired pain modulation with central sensitization can cause NP (810). Due to the characteristic complaints of NP reported by our patients, we consider that there is a NP component in the pain of knee after arthroplasty. The prevalence of NP after TKA was analyzed in the review of Drosos et al. (11). Mentioned review reported that NP exists in a significant proportion of patients for years after TKA. Although the literature suggests that NP peaks at between six weeks and three-months after $\operatorname{TKA}(7,12)$, the presence of NP in the long-term follow-up period after TKA is not underestimated for pain management. Therefore we designed a prospective study involving a cohort of patients underwent TKA at least one year ago.

The risk factors for persistent pain after knee arthroplasty have been identified $(1,13)$ in some studies. To our knowledge, a limited number of studies have evaluated the relationship between risk factors and NP after TKA (14). No firm conclusions were reported about the prevalence of NP and the related factors due to the heterogeneity of the studies in the literature (11). The risk factors of NP due to TKA should be determined to obtain successful results after TKA (14).

Our objectives were to examine first the presence of NP at least one year after TKA and second its association with socio-demographic factors, physical function, medical and psychological comorbidities.

\section{Materials and Methods}

A total of 85 female patients with TKA evaluated in the study. Ethical approval was obtained from the Ankara Physical Medicine and Rehabilitation Training and Research Hospital Ethics Committee (decision no: 5995, date: 29.12.2014). A written informed consent was obtained from each patient. The study was conducted in accordance with the principles of the Declaration of Helsinki. All patients underwent artroplasty due to knee osteoarthritis at least one year ago.

The exclusion criteria were presence of inflammatory diseases, radiculopathies, vitamin B12 deficiency, coxarthrosis, neurological conditions and receiving medical treatment for NP.

Socio-demographic factors including age,job,education, body mass index (BMI), marital status and medical (hearth disease, hypertension, diabetes mellitus, chronic obstructive pulmonary disease, thyroid dysfunction, osteoporosis, hypercholesterolaemia) and psychological (anxiety and depression) comorbidities were questioned. All patients completed the visual analog scale (VAS) for pain at preoperation and postoperation, Western Ontario and McMaster Universities osteoarthritis index (WOMAC) scale, the PainDETECT questionnaire (PDQ) and the hospital anxiety depression scale (HADS).

The VAS was used to assess the preoperative and post-operative pain levels. It consists of a $10 \mathrm{~cm}$ line, with the left extreme indicating "no pain or zero" and the right extreme indicating "unbearable pain or 10" (15).

WOMAC scale was used to assess the functional status. It is divided into 3 subgroups that address pain, stiffness and physical functionality. It consists of 24 questions including 5 questions for the pain subgroup, 2 questions for the stiffness subgroup, and 17 questions for the physical functionality subgroup. Each item is recorded using a 5-point Likert form, 0 is none while 4 is extreme pain, with 0 as the best and 96 as the worst. The Turkish reliability and validity studies were conducted (16).

PDQ is a scale to evaluate NP experienced by paints in the preceding four weeks. It contains a body drawing for patients to indicate the sites of pain and any radiation present, assessment of pain quality with a marker of severity from hardly noticed to very strongly, pattern of pain and measures of current, worst and average pain severity. The PainDETECT score ranged from 0 to 38 . Score $\geq 19$ indicate likely NP, score $\geq 13$ to $\leq 18$ indicate possible NP, score $\leq 12$ indicate unlikely NP (17). The Turkish version of the PDQ and validation were proven by Alkan et al. (18)

HADS is a scale to assess the emotional status of the patient's. It consists of 2 subscales containing questions about anxiety (7 items) and depression (7 items). Items are recorded using a 4-point Likert form ranging from 0 to 3. Seven point is used as the cut-off score for depression subscale and 10 point for anxiety subscale (19).

\section{Statistical Analysis}

SPSS version 20.0 (SPSS Inc., Chicago, IL, USA) was used for the statistical analyses. Distributions of continuous variables were evaluated by the Shapiro-Wilk test. Continuous variables were expressed as mean \pm standard deviation; discrete variables as median (minimum-maximum), and categorical variables as number ( $\mathrm{n}$ ) and percentage (\%). One-Way ANOVA and chisquare tests were used to evaluate demographic and clinical characteristics of patients between the three NP groups (likely, possible and unlikely NP). The linear relationships between PainDETECT scores and other clinical variables were evaluated with Pearson correlation analysis. Multiple regression analysis was used to investigate the clinical and socio-demographical factors affecting PainDETECT scores. A p-value of $<0.05$ was evaluated as statistically significant.

\section{Results}

Eighty five female patients with a mean age of 70.28 \pm 7.22 years were included in the study. All patients had knee pain 
after arthroplasty, 9 (10.6\%) patients were classified as having likely NP, 14 (16.5\%) patients were classified as having possible NP and 62 (72.9\%) patients were classified as unlikely NP (nociceptive group). Average duration after arthroplasty was $5.48 \pm 3.83$ years. Socio-demographic characteristics and clinical properties of the patients are shown in Table 1. Demographic and clinical characteristics of patients based on PainDETECT scores are shown in Table 2. When we divided patients into three groups according to the PainDETECT scores, there was no statistically significant difference in demographic features between three groups. There were statistically significant differences in WOMAC pain score $(p<0.001)$ and WOMAC physical function score $(p<0.001)$ between NP groups (group 2 and 3) and nociceptive group (group 1). In addition, there were statistically significant differences in depression $(p<0.001)$ and anxiety scores of HAD ( $p=0.004$ ) between group 1 (nociceptive group) and group 3 (likely NP group).

Table 1. Socio-demographic characteristics and clinical properties of the patients

\begin{tabular}{|l|l|l|}
\hline & Mean \pm SD & $\mathbf{n}(\%)$ \\
\hline Body mass index $\left(\mathrm{kg} / \mathrm{m}^{2}\right)$ & $33.8 \pm 4.7$ & - \\
\hline Age (year) & $70.2 \pm 7.2$ & - \\
\hline Work status & &
\end{tabular}

\begin{tabular}{|c|c|c|}
\hline Housewife & - & $81(95.3)$ \\
\hline Retired & - & $4(4.7)$ \\
\hline \multicolumn{3}{|l|}{ Educational status } \\
\hline Illiterate & - & $22(25.9)$ \\
\hline Primary school & - & $57(67.1)$ \\
\hline High school-university & - & $6(7.1)$ \\
\hline Time frame & $5.4 \pm 3.8$ & - \\
\hline Preop VAS & $9.2 \pm 0.8$ & - \\
\hline Post-op VAS & $2.7 \pm 2.1$ & - \\
\hline HADS & $18.6 \pm 8.1$ & - \\
\hline \multicolumn{3}{|l|}{ HADS scores } \\
\hline Depression & $9.0 \pm 3.8$ & - \\
\hline Anxiety & $9.7 \pm 5.4$ & - \\
\hline WOMAC scores & - & - \\
\hline Pain & $5.3 \pm 3.7$ & - \\
\hline Physical function & $27.2 \pm 10.9$ & - \\
\hline PainDETECT Q scores & $6.8 \pm 7.3$ & - \\
\hline \multicolumn{3}{|l|}{ PDQ groups } \\
\hline Unlikely neuropathic pain & - & $62(72.9)$ \\
\hline Possible neuropathic pain & - & $14(16.5)$ \\
\hline Likely neuropathic pain & - & $9(10.6)$ \\
\hline \multicolumn{3}{|c|}{$\begin{array}{l}\text { SD: Standard deviation, VAS: Visual analog scale, HADS: The hospital anxiet } \\
\text { and depression scale, WOMAC: Western Ontario and McMaster Universitie } \\
\text { osteoarthritis index, PDQ: PainDETECT questionnaire. Likely neuropathi } \\
\text { pain (score } \geq 19 \text { ), possible neuropathic pain (score } \geq 13 \text { to } \leq 18 \text { ), and unlikel } \\
\text { neuropathic pain (score } \leq 12 \text { ) }\end{array}$} \\
\hline
\end{tabular}

The correlation analysis with PainDETECT scores is shown in Table 3. The PainDETECT scores were significantly correlated with the preoperative VAS scores, WOMAC pain and physical function scores and presence of depression. The PainDETECT scores were significantly negatively correlated with time frame after arthroplasty. There was no correlation between PDQ scores and age or presence of anxiety.

\section{Discussion}

Our study results showed that patients with shorter time frame after TKA had NP in their joint pain and that patients who reported NP exhibited increased pain, decreased physical function and presence of depression compared with patients who reported nociceptive pain. We found no relationship between NP and socio-demographic factors or medical comorbidities.

The prevalence of NP after TKA ranges from $6-49 \%$ in previous studies $(20,21)$. Wylde et al. (20) found that $6 \%$ of patients had NP 3-4 years after TKA. Pinto et al. (21) reported that NP was seen in $49 \%$ of patients, according to the Neuropathic Pain Questionnaire 4-6 months after TKA. Using the PDQ score, the rate of NP was determined to be $15.3 \%$ of all patients after TKA in the study of Albayrak et al. (14). In our study the prevalence of NP was $10.6 \%$ at least one year after TKA (Average duration after arthroplasty was $5.48 \pm 3.83$ years). Our study confirms the presence of NP after TKA and indicates that NP can exist in the long-term followup period after TKA. Differences in assessment tools and postsurgical time frames may explain the discrepancies among these studies. Peripheral nerve injury during surgery or impaired pain modulation with central sensitization can cause NP (8).

The association between preoperative pain and NP after TKA has been reported difference in studies $(12,14)$. In our study, patients with high preoperative VAS scores exhibited NP after TKA. Thus preoperative pain may be considered as a risk factor of NP after TKA. Severe pain before operation may change the somatosensory system, impair pain modulation, and increase the risk of chronic pain even after operation (6).

The effect of socio-demographic factors on pain after TKA has been examined in several studies $(7,13,22-28)$. A better understanding of risk factors for NP is critical to allow patients to have appropriate expectations of TKA. Previous studies reported that gender and age did not predict the development of NP after TKA $(22,23)$. Some studies showed that marital status, educational level and occupation may play roles in pain after TKA $(26,27)$. Another study showed that age and obesity do not have a negative impact on pain after TKA (24). In our study, there was no difference in age, BMI, educational level, marital status and job between groups. We consider that this may be a result of all of our patients were female and most of them being housewives and having a low level of education.

The association between the medical comorbidities and persistent pain after TKA has been investigated in the literatures $(13,22)$. However, it is unknown which comorbidities are associated with NP after TKA. Heart disease, anxiety and depression were 
Table 2. Demographic and clinical characteristics of patients based on PainDETECT scores

\begin{tabular}{|c|c|c|c|c|}
\hline & $\begin{array}{l}\text { Unlikely NP ( } n=62 \text { ) } \\
\text { Nociceptive group }\end{array}$ & Possible NP (n=14) & Likely NP (n=9) & $\mathbf{p}$ \\
\hline Age (year) & $70.72 \pm 6.93$ & $69.21 \pm 8.49$ & $68.88 \pm 7.65$ & 0.16 \\
\hline \multicolumn{5}{|l|}{ Marital status } \\
\hline Maried & $43(69.4)$ & $7(50)$ & $5(55.6)$ & \multirow{2}{*}{0.32} \\
\hline Widowed & $19(30.6)$ & $7(50)$ & $4(44.4)$ & \\
\hline BMI $\left(\mathrm{kg} / \mathrm{m}^{2}\right)$ & $33.37 \pm 4.53$ & $35.28 \pm 5.96$ & $34.95 \pm 3.79$ & 0.30 \\
\hline \multicolumn{5}{|l|}{ Educational status } \\
\hline Illiterate & $13(21)$ & $6(42.9)$ & $3(33.3)$ & \multirow{3}{*}{0.43} \\
\hline Primary school & $44(71)$ & $7(50)$ & $6(66.7)$ & \\
\hline High school & $5(8)$ & $1(7.1)$ & 0 & \\
\hline \multicolumn{5}{|l|}{ Work status } \\
\hline Housewife & $58(93.5)$ & $14(100)$ & $9(100)$ & \multirow{2}{*}{0.45} \\
\hline Retired & $4(6.5)$ & - & - & \\
\hline ROM flexion & $102.33 \pm 16.78$ & $103.92 \pm 12.27$ & $92.77 \pm 13.48$ & 0.12 \\
\hline Time after arthroplasty (year) & $5.2 \pm 3.72$ & $7.21 \pm 4.11$ & $4.7 \pm 3.88$ & 0.63 \\
\hline Preop VAS & $9.16 \pm 0.83$ & $9.71 \pm 0.61$ & $9.55 \pm 1.01$ & 0.28 \\
\hline Post-op VAS & $1.9 \pm 1.46$ & $4.2 \pm 1.58$ & $5.77 \pm 1.56$ & 0.63 \\
\hline \multicolumn{5}{|l|}{ Comorbidites } \\
\hline Diabetes mellitus & $22(35.5)$ & $7(50)$ & $2(22.2)$ & 0.35 \\
\hline Hypertension & $41(66.1)$ & $10(71.4)$ & 8 (88.9) & 0.40 \\
\hline Thyroid disorders & $19(30.6)$ & $1(7.1)$ & $2(22.2)$ & 0.18 \\
\hline Hearth disease & $12(19.4)$ & 0 & $1(11.1)$ & 0.14 \\
\hline $\begin{array}{l}\text { Chronic obstructive } \\
\text { pulmonary disease }\end{array}$ & $7(11.3)$ & $1(7.1)$ & $1(11.1)$ & 1 \\
\hline WOMAC pain & $3.83 \pm 2.80$ & $9.21 \pm 3.49$ & $9 \pm 9.44$ & $<0.001^{a, b}$ \\
\hline WOMAC physical function & $23.88 \pm 9.6$ & $32.52 \pm 8.96$ & $41.88 \pm 6.37$ & $<0.001^{a, b}$ \\
\hline HAD total & $16.87 \pm 7.24$ & $20.57 \pm 8.17$ & $27.66 \pm 8.3$ & $<0.001^{b}$ \\
\hline HAD depression & $8.04 \pm 3.44$ & $10.42 \pm 2.95$ & $13.44 \pm 3.84$ & $<0.001^{b}$ \\
\hline HAD anxiety & $8.83 \pm 4.92$ & $10.21 \pm 6$ & $15.11 \pm 5.08$ & $0.004^{b}$ \\
\hline
\end{tabular}

Table 3. The regression analysis with PainDETECT scores

\section{Unstandardized coefficients} standard error

\begin{tabular}{|l|l|l|l|l|}
\hline & B & p & Lower & Upper \\
\cline { 2 - 5 } & -21.323 & 0.013 & -38.038 & -4.609 \\
\hline Age & -0.022 & 0.772 & -0.173 & 0.129 \\
\hline Time after arthroplasty & -0.318 & 0.033 & -0.609 & -0.027 \\
\hline Preop VAS & 2.015 & 0.004 & 0.676 & 3.355 \\
\hline HAD depression & 0.438 & 0.021 & 0.067 & 0.810 \\
\hline HAD anxiety & -0.110 & 0.370 & -0.353 & 0.133 \\
\hline WOMAC pain & 0.915 & 0.000 & 0.532 & 1.297 \\
\hline WOMAC physical function & 0.182 & 0.007 & 0.052 & 0.311 \\
\hline Cl: Confidence interval, HAD: The hospital anxiety and depression, WOMAC: Western Ontario and McMaster Universities osteoarthritis index, VAS: Visual analog scale \\
\hline
\end{tabular}

\section{$95 \% \mathrm{Cl}$}


reported as risk factors for persistant pain after TKA in the study of Singh and Lewallen (13). Depression has been reported to affect the pain after TKA in several studies $(22,23,28,29)$. But Philips et al. (7) did not find any significant influence of depression on persistant pain in their study. Although there was no association between comorbidities and NP after TKA in the study of Helen Razmjou, they found that the NP group had higher levels of depression in their study (22). Consistent with this study we found that depression was associated with NP after TKA, but we didn't find any correlation between other comorbidities and NP in the TKA patients. According to these findings, we consider that depression may be a risk factor for NP after TKA, can set the scene for chronic pain and should be identified and treated. The effect of other comorbidities on NP after TKA requires further examination. Previous studies showed that patients with NP after TKA reported higher levels of pain and physical dysfunction as measured by domains of the WOMAC $(22,23)$. Our results are consistent with these studies in terms of the relation between NP and increased severity of pain and physical dysfunction after TKA.

\section{Study Limitations}

Our study has some limitations. First, all of our patients were female and sample size was small. The results may be different in larger sample size with male patients. Second, TKA were undertaken by different surgeons and the complications after TKA were not controlled. These parameters may effect the evaluation of pain. And another limitation was the lack of control group who do not have any pain after TKA. Further research using a larger sample size with control group is suggested.

\section{Conclusion}

Our findings highlight the importance of an assessment of NP after TKA. NP was related to preoperative pain and depression. Patients reporting NP showed increased severity of pain and decreased physical function. Therefore, the presence of NP in the TKA patients should be considered and assosiated factors should be evaluated. Once it is determined, appropriate intervention strategies for NP should be incorporated in the treatment of persistent pain after TKA.

\section{Ethics}

Ethics Committee Approval: Ethical approval was obtained from the Ankara Physical Medicine and Rehabilitation Training and Research Hospital Ethics Committee (decision no: 5995, date: 29.12.2014).

Informed Consent: A written informed consent was obtained from each patient.

Peer-review: Externally peer-reviewed.

\section{Authorship Contributions}

Surgical and Medical Practices: C.S.P., Concept: C.S.P., B.F.K., Design: C.S.P., B.F.K., Data Collection or Processing: C.S.P., E.U.A., Analysis or Interpretation: C.S.P., D.S.Ö., Ş.S. O., Literature Search: C.S.P., B.F.K., Ş.Ş.O., Writing: C.S.P., D.S.Ö.
Conflict of Interest: No conflict of interest was declared by the authors.

Financial Disclosure: The authors declared that this study has received no financial support.

\section{References}

1. Lewis GN, Rice DA, McNair PJ, Kluger M. Predictors of persistent pain after total knee arthroplasty: a systematic review and metaanalysis. Br J Anaesth 2015;114:551-61.

2. Pinto $P R$, Mclntyre $T$, Ferrero $R$, Almeida $A$, Araújo-Soares $V$. Risk factors for moderate and severe persistent pain in patients undergoing total knee and hip arthroplasty: a prospective predictive study. PLoS One 2013;8:e73917.

3. Protzman NM, Gyi J, Malhotra AD, Kooch JE. Examining the feasibility of radiofrequency treatment for chronic knee pain after total knee arthroplasty. PM R 2014;6:373-6.

4. Chughtai M, Elmallah RD, Mistry JB, Bhave A, Cherian JJ, McGinn $T L$, et al. Nonpharmacologic Pain Management and Muscle Strengthening following Total Knee Arthroplasty. J Knee Surg 2016;29:194-200.

5. Beswick AD, Wylde V, Gooberman-Hill R, Blom A, Dieppe P. What proportion of patients report long-term pain after total hip or knee replacement for osteoarthritis? A systematic review of prospective studies in unselected patients. BMJ Open 2012;2:e000435.

6. Vergne-Salle P. Management of neuropathic pain after knee surgery. Joint Bone Spine 2016;83:657-63.

7. Phillips JR, Hopwood B, Arthur C, Stroud R, Toms AD. The natural history of pain and neuropathic pain after knee replacement: a prospective cohort study of the point prevalence of pain and neuropathic pain to a minimum three-year follow-up. Bone Joint J 2014;96-B:1227-33

8. Kehlet $\mathrm{H}$, Jensen TS, Woolf $\mathrm{CJ}$. Persistent postsurgical pain: risk factors and prevention. Lancet 2006;367:1618-25.

9. Haroutiunian S, Nikolajsen L, Finnerup NB, Jensen TS. The neuropathic component in persistent postsurgical pain: a systematic literature review. Pain 2013;154:95-102.

10. Wright A, Moss P, Sloan K, Beaver RJ, Pedersen JB, Vehof G, et al. Abnormal quantitative sensory testing is associated with persistent pain one year after TKA. Clin Orthop Relat Res 2015;473:246-54.

11. Drosos GI, Triantafilidou T, Ververidis A, Agelopoulou C, Vogiatzaki T, Kazakos K. Persistent post-surgical pain and neuropathic pain after total knee replacement. World J Orthop 2015;6:528-36.

12. Fuzier $R$, Rousset J, Bataille $B$, Salces-y-Nédéo $A$, Maguès JP. One half of patients reports persistent pain three months after orthopaedic surgery. Anaesth Crit Care Pain Med 2015;34:15964.

13. Singh JA, Lewallen DG. Medical and psychological comorbidity predicts poor pain outcomes after total knee arthroplasty. Rheumatology (Oxford) 2013;52:916-23.

14. Albayrak I, Apiliogullari S, Erkocak OF, Kavalci H, Ozerbil OM, Levendoglu F. Total Knee Arthroplasty due to Knee Osteoarthritis: Risk Factors for Persistent Postsurgical Pain. I Natl Med Assoc 2016;108:236-43

15. Tok F, Aydemir K, Peker F, Safaz I, Taşkaynatan MA, Ozgül A. The effects of electrical stimulation combined with continuous passive motion versus isometric exercise on symptoms, functional capacity, quality of life and balance in knee osteoarthritis: randomized clinical trial. Rheumatol Int 2011;31:177-81.

16. Tüzün EH, Eker L, Aytar A, Daşkapan A, Bayramoğlu M. Acceptability, reliability, validity and responsiveness of the Turkish version of WOMAC osteoarthritis index. Osteoarthritis Cartilage 2005; 13:28-33

17. Freynhagen R, Baron R, Gockel U, Tölle TR. painDETECT: a new screening questionnaire to identify neuropathic components in patients with back pain. Curr Med Res Opin 2006;22:1911-20.

18. Alkan H, Ardic F, Erdogan C, Sahin F, Sarsan A, Findikoglu G. Turkish version of the painDETECT questionnaire in the assessment 
of neuropathic pain: a validity and reliability study. Pain Med 2013;14:1933-43.

19. Aydemir O, Guvenir T, Kuey L. Hastane anksiyete ve depresyon ölceği turkce formunun geçerlilik ve güvenilirlik çalışması. Turk Psikiyatri Dergisi 1997;8:280-7.

20. Wylde V, Hewlett S, Learmonth ID, Dieppe P. Persistent pain after joint replacement: prevalence, sensory qualities, and postoperative determinants. Pain 2011;152:566-72

21. Pinto $P R, M c I n t y r e ~ T$, Ferrero $R$, Araújo-Soares $V$, Almeida $A$ Persistent pain after total knee or hip arthroplasty: differential study of prevalence, nature, and impact. J Pain Res 2013;6:691703.

22. Razmjou H, Boljanovic D, Wright S, Murnaghan J, Holtby R. Association between Neuropathic Pain and Reported Disability after Total Knee Arthroplasty. Physiother Can 2015;67:311-8.

23. Wylde V, Jeffery A, Dieppe P, Gooberman-Hill R. The assessment of persistent pain after joint replacement. Osteoarthritis Cartilage 2012;20:102-5.

24. Hawker G, Wright J, Coyte P, Paul J, Dittus R, Croxford R, et al. Health-related quality of life after knee replacement. J Bone Joint Surg Am 1998;80:163-73
25. Singh JA, Gabriel SE, Lewallen DG. Higher body mass index is not associated with worse pain outcomes after primary or revision total knee arthroplasty. J Arthroplasty 2011;26:366-374.e1.

26. Lavand'homme PM, Grosu I, France MN, Thienpont E. Pain trajectories identify patients at risk of persistent pain after knee arthroplasty: an observational study. Clin Orthop Relat Res 2014;472:1409-15.

27. Ethgen $O$, Bruyère $O$, Richy $F$, Dardennes $C$, Reginster JY. Healthrelated quality of life in total hip and total knee arthroplasty. A qualitative and systematic review of the literature. J Bone Joint Surg Am 2004;86:963-74.

28. Brander V, Gondek S, Martin E, Stulberg SD. Pain and depression influence outcome 5 years after knee replacement surgery. Clin Orthop Relat Res 2007;464:21-6.

29. Hanusch BC, O'Connor DB, Ions P, Scott A, Gregg PJ. Effects of psychological distress and perceptions of illness on recovery from total knee replacement. Bone Joint J 2014;96-B:210-6. 